\title{
Artists/Ceramists in the Role of University Teachers
}

\section{Silvie Novotná ${ }^{1}$}

$\approx$ The teaching of ceramics is a topic that has been much discussed in pedagogical discourse throughout the entire second half of the twentieth century and until today. The present study deals with the topic of third-level education in the field of ceramics at Palacký University Olomouc, Czech Republic. The incorporation of ceramics into the education of future art teachers in Olomouc was not always a matter of course as it is today. It underwent many changes during the second half of the twentieth century. Several personalities played an important role in the process of the gradual consolidation of its position in pedagogical education. The most important of these are presented in this study. It describes their main contribution to the field, deals with their attitudes to teaching ceramics, and above all analyses the interconnection of their own art or scientific research theoretical work with the content of teaching. The historical-methodological study connects its theme with historical socio-political events, as well as with the development of fine arts in the second half of the twentieth century. Thus, it contributes to the formation of a comprehensive picture of the topic »artists as art teachers « in the Europe-wide context.

Keywords: ceramics, applied art of the second half of the twentieth century, Palacký University Olomouc 


\section{Umetniki/Keramiki v vlogi univerzitetnih učiteljev}

Silvie Novotná

$\approx$ Poučevanje keramike je tema, o kateri se razpravlja v celotni drugi polovici 2o. stoletja vse do danes. Ta študija obravnava temo tretjestopenjskega izobraževanja na področju keramike na Univerzi Palacký Olomouc na Češkem. Vključevanje vsebin keramike v izobraževanje prihodnjih likovnih pedagogov v Olomoucu ni bilo vedno samoumevno. V drugi polovici 20. stoletja je program doživel številne spremembe. Številne osebnosti so igrale pomembno vlogo v postopnem utrjevanju vsebin keramike v pedagoškem izobraževanju. Najpomembnejši med njimi so predstavljeni v tej študiji. Prispevek opisuje njihove zasluge na tem področju, obravnava njihov odnos do poučevanja keramike, predvsem pa analizira medsebojno povezanost lastnega likovnega ali znanstvenoraziskovalnega - teoretičnega dela $\mathrm{z}$ vsebino poučevanja. Zgodovinsko-metodološka študija svojo temo povezuje z zgodovinskimi družbenopolitičnimi dogodki pa tudi z razvojem likovne umetnosti $v$ drugi polovici 2o. stoletja. Tako prispeva k oblikovanju celovite slike teme »umetniki kot likovni pedagogi« v evropskem kontekstu.

Ključne besede: keramika, uporabna umetnost druge polovice 20 . stoletja, Univerza Palacký Olomouc 


\section{Introduction}

Working with clay is an ancient field of human activity. Clay objects have accompanied humankind throughout history and to some extent have always been a measure of the maturity of a civilisation (Warshawová, 1999). Budak (2017, p. 12) highlights thousands of years of the ceramics tradition with the engaging words »ceramics have kept humans in close company since the Neolithic Age; it represents perhaps the most varied and versatile material, both humble and refined, noble and mundane, simple and costly, used in everyday life as well as in palaces and in rituals«. Creative work with clay has always enriched and deepened the relationship of a human being to matter, material and structure, supporting creativity and spatial imagination, and developing fine motor skills and the ability of tactile perception and tactile experience. Its relaxing effect is undeniable, especially in today's over-technological world. According to Šicková-Fabrica (2008, p. 136), clay and activities associated with it (squeezing, shaping, manual modelling, imprinting, etc.) are also suitable »for breaking through barriers of fear, as a material replacing verbal communication, for eliminating aggressive behaviour, for the development of imagination, threedimensional perception, for the creation of space for foresight as a background for changing attitudes towards oneself and others«. Working with clay offers experiences that contribute positively to the development of an individual.

Despite these facts, creative work with clay earned its place in the primary education system only gradually, and unfortunately even today, its inclusion in art lessons is not a matter of course. Whether working with clay is implemented in compulsory education depends not only on the technical capabilities of schools or the support of their management, but above all on the attitudes, abilities and interests of art teachers themselves. In this respect, the motivation and experience that teachers gain during their training for their profession is crucial, and the individual university personalities who impact their teacher training play a paramount role.

At Palacký University Olomouc today, ceramic art making, as one of the possible methods of creative work with clay, is an integral part of the art teacher training programme. However, ceramics did not always enjoy its current position as an independent taught subject at the university; it had to build it gradually during the decades of the development of university art education.

The history of the University of Olomouc has been addressed in many studies and in a number of publications. Bieberle (1996, 2003, 2011, 2016), Horejsek (1996), Kováríčck $(1996,2005)$ and a teams of authors (Fiala et al., 2009; University Palacký, Faculty of Education \& Kováŕíček, 2006a, 2006b; University 
Palacký, Faculty of Education \& Serafín, 2005; University Palacký, Faculty of Education, 2016; Urbášek et al., 2003) evaluate the topic in texts published after the change of political regime in 1989. Due to the spread of the topic, they do not focus on the field of art, and therefore the teaching of ceramics is not evaluated in any way in these texts., They nevertheless form key study material, as they provide a quality basis of the socio-historical context for the subject of research. A critical assessment of the history and the present situation of teaching at the Department of Art Education is given in texts by Myslivečková (e.g., 2002, 2018) or in collective monographs by members of the Department of Art (Myslivečková \& Šobáňová, 2007, 2014; University Palacký, Faculty of Education, 2007).

To date, the development and changes in the field of art and pedagogy at Palacký University Olomouc have been most comprehensively evaluated in the publication entitled Josef Vydra (1884 - 1959) v kontextu umělecké a výtvarně pedagogické avantgardy 20. století. Historie a současnost univerzitního výtvarného vzdělávání v Olomouci [Josef Vydra (1884-1959) in the Context of the Art and Art Pedagogical Avant-Garde of the Twentieth Century. The History and Present of University Art Education in Olomouc] (Kavčáková \& Myslivečková, 2010). However, the text contains only fragmentary information about the teaching of ceramics. Significant factual data, extremely valid at the time, are provided in publications or articles published by the university on the occasion of various anniversaries (e.g., Dvořák, 1976; Navrátil, 1973; Novák, 1976; Přikryl, 1976; University Palacký, 1983, 1984) and in small catalogues of art exhibitions of students' and teachers' artworks (e.g., 1970, 1973, 1981). Catalogues accompanying individual or collective exhibitions of independent artworks of teachers also have a significant informative value, but they do not critically evaluate teaching practice.

Since the post-war period, the interest in integrating the teaching of ceramics into teacher training programmes has been closely connected not only to cultural and political context, but also to the development of pedagogical-psychological professional discourse. In particular, key professional studies on the ontogenesis of children's artistic expression that classify the three-dimensional artistic expression of children by Krautter (1930), Lowenfeld (1947), Bender (1952) or Osten (1965, pp. 87-92) drew attention to the need for the development of the individual in the area of three-dimensional artmaking, as well. A major contribution to the development of the study of children's artistic expression in the Czech lands was made by the texts entitled Vnímání a výtvarný projev [Perception and Artistic Expression] (1970), Výtvarný projev a výchova [Artistic Expression and Education] (1974), and the overview publication entitled Čáry, klikyháky, paňáci a auta [Lines, Scribbles, Panners and Cars] (1974) by Uždil. Although these texts deal with children's drawing in psychological and didactic contexts, they also 
reflect on other art techniques, including modelling from clay. Within the theory and methodology of Czech art pedagogy, interest in integrating ceramics into the concept of teaching art education culminated in works by Zhoř $(1995,1996)$, Cikánová (1995) and Roeselová (1996, 1997, 1999).

Teaching in the field of ceramic work was introduced into the framework of the third-level art teacher training programme in Olomouc as early as in 1946. However, the description, analysis and evaluation of this segment of education in Olomouc has not yet been theoretically reflected on. To date, no comprehensive study has been prepared dealing with the pedagogical practice of individual teachers of ceramics either at the University of Olomouc or at associated workplaces (Pedagogical Institute, Pedagogical University).

The presented historical-methodological study focuses on ceramics education at Palacký University Olomouc from 1946, which marks the renewal of third-level education in Olomouc, to the present. The study selects the personalities who played the most important role in the integration and gradual consolidation of the position of teaching ceramics, analyses their importance for the field, and examines and evaluates the extent to which their own works were connected and interacted with the goals and content of teaching, as well as the student requirements. The personality of Jaroslav Nerad, whose teaching has been obscured by the course of history, is excluded from the study. Although research has shown a high proportion of ceramic work in Zdeněk Přikryl's modelling lessons, due to his primary focus on sculpture he is not included in the study either. The topic of the study is placed within the contemporary socio-political climate and is connected with events that occurred in fine arts in the second half of the twentieth century in the Czech lands. It monitors the development of teaching ceramics and its qualitative changes primarily in connection with the personalities of individual teachers. The text follows the latest published works of the author entitled Výuka keramiky na Univerzitě Palackého $v$ Olomouci v minulosti a dnes [Teaching Ceramics at Palacký University Olomouc in the Past and Now] (Novotná, 2019) and Vývoj a kvalita výuky keramiky $v$ rámci vysokoškolského vzdělávání [The Development and Quality of Teaching Ceramics in University Education] (Novotná, 2019).

\section{Research questions}

In order to define the scope of the subject matter, the following initial research questions were set: Which personalities fundamentally contributed to the development of education in the field of third-level teaching of ceramics in Olomouc? What was their contribution to the field? What were/are their 
attitudes towards teaching ceramics? In what way and to what extent was their own artistic or scientific research theoretical work interconnected with the content of teaching?

\section{Method}

The study presents the results obtained during long-term historicalpedagogical research. It presents knowledge gained from mixed research, as it is a combination of qualitative and quantitative research, using methods of historical and pedagogical research (study of primary sources, secondary literature, interviews with direct participants or witnesses of observed events, observation, analysis of verbal statements, content analysis). The study of primary sources consisted mainly of the analysis and critical evaluation of archival materials from university sources, primarily of the complete Lists of Lectures of Palacký University Olomouc from 1946 to the present, Registers of Diploma Theses and volumes of Records of Diploma Theses, as well as all final (master's) theoretical and practical theses on ceramics from the first one dated 1951/1952. Furthermore, official study materials (university textbooks) and private texts of former and current teachers of ceramics were collected and analysed, as well as records of lectures or other notes taken by graduates. Last but not least, as a method of collecting data on the pedagogical reality, a number of semi-structured interviews were held with former and current teachers (Teplý, Hejný, Přikryl, Bébarová, Selingerová, Dokoupilová, Buček), graduates (Ovčáčková, Marková, Varmuža, Kocábová, Otrusinová, Koláčková, Stiborová, Poláková, Outlá, Tarašková, Vlčková) and other witnesses whose statements were relevant to the subject matter of the research (e.g., Vymětalová, Ovčáček).

\section{Results}

The institutional training of art teachers in the field of teaching ceramics was faced with many twists in the second half of the twentieth century in Olomouc. The introduction of ceramics into teaching, its expansion and the stabilisation of its position to the point where it became an independent compulsory subject was influenced not only by the opinions of the heads of art departments (institutes) of the Faculty of Education and Faculty of Arts or associated workplaces (Pedagogical Institute, Pedagogical University) in Olomouc, but mainly by the ambitions, interests and attitudes of individual teachers of the subjects in which ceramics was included. Moreover, the quality and content as well as the formal and thematic focus of the teaching of ceramics were predestined not 
only by contemporary art tendencies or priorities in the general socio-cultural context, but primarily by the own artmaking or scientific research work of the given teachers.

\section{Difficult beginnings in the post-war period}

World War II ended in victory for the allies; Czechoslovakia was restored. However, it was not possible to revive the First Republic democracy; society was strongly pro-Soviet and the government was rather authoritarian. The state »began to programmatically build a new socialist world with a new man and created a system of precise instructions for meeting his needs. The motto of the time became »coordinated planning', which was supposed to guarantee a reasonable arrangement, no longer limited as before by »the whims of private property' and "unorganized ideas", where economic life was defined by entrepreneurial arbitrariness« (Skřivánková, 2016, p. 325). The post-war situation was further complicated by the events that took place in February 1948, when the Communists seized power in Czechoslovakia. Citizens were guaranteed some social security, but at the same time their basic human rights and freedoms were curtailed. At the Congress of National Culture in Prague in April 1948, the requirements for a new role for artists in society were clearly formulated (Kouřil, 1948; Zeman, 2007, p. 32). Politically engaged works aimed at creating a new, socialist culture were to be preferred and generally accepted. For the fine arts, 1948 meant not only the forced cessation of avant-garde groups that sought their theoretical foundations in the interwar art of civilism, cubism, futurism, constructivism or surrealism (e.g., Group 42, the RA Group), but also a number of other changes that had an adverse effect on the further development of Czech fine art.

Even for applied and freestyle ceramic works, the situation in post-war Czechoslovakia was not favourable. After World War II, the Union of Czechoslovak Works (founded in 1914 as the Union of Czech Works), »an institution with an avant-garde programme« (Petrová, 2005a, p. 267) supporting the art industry and designers themselves, continued to develop its activities, but in 1948 it merged with the Headquarters of Folk and Art Production, a corporation that during the 1950s, "narrowed its scope only to the protection and development of folk art production « (Žižková, 2008, p. 131). Ceramic production was also significantly negatively affected by the war and the events that ensued. Post-war nationalisation led to lower competitiveness of companies, limited quality of products and lower demands on product design. The closure of vocational secondary schools during the war resulted in the loss of experts, 
not only in business and administration, but mainly specialists in the field. In Prague, the activities of the Academy of Arts, Architecture and Design were terminated in 1944, as well as other schools, including the State Vocational School of Ceramics. Ceramics of the post-war years thus had to face the difficult task of maintaining its own high quality while waiting for the moment to build on its industrial and artistic production. Petrová (2005a) finds these enduring values mainly in the studios and workshops of artists who established themselves, or at least graduated, in the pre-war period. In addition to Julia Kováčiková-Horová and Vincenc Vingler, Otto Eckert was one of these artists. After World War II, he took over the area of teaching ceramics in Prague at the renewed Academy of Arts, Architecture and Design. Eckert was a state-sponsored artist who participated in dozens of exhibitions and competitions not only in Czechoslovakia but also abroad (e.g., Expo Brussels, 1958; International Exhibition of Ceramics, Ostende, 1959). Through his pedagogical work and his own work, he maintained and further developed the tradition of Czech ceramics and became a personality influencing several other generations of Czech ceramics. The breadth of his work not only impacted the territory of the capital city of Prague, but spread throughout the country. One of the admirers of his work was Stanislav Vymětal (1929-1992), a generation younger and a student of the University of Olomouc.

\section{Figure 1}

Otto Eckert, Vases, 1964, Regional Museum in Olomouc, photo by P. Rozsíval

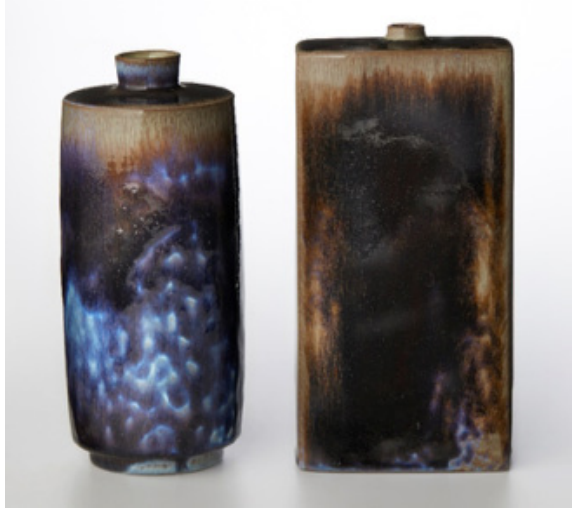




\section{Figure 2}

Otto Eckert, Vase, 1962, Regional Museum in Olomouc, photo by P. Rozsíval

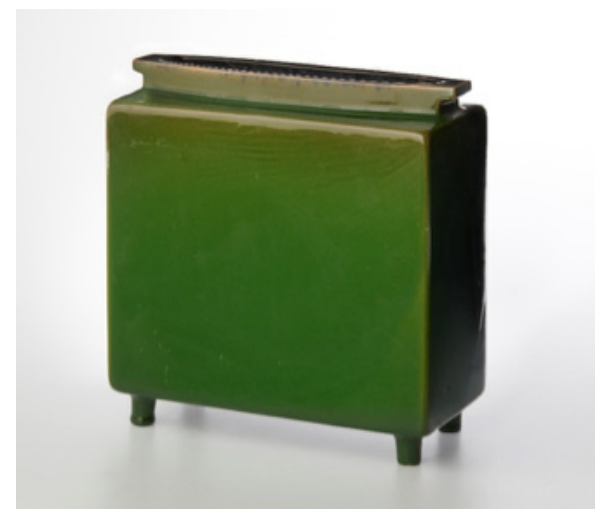

\section{Olomouc introduces the teaching of ceramics}

There was no tradition of third-level teaching of ceramics in Olomouc that could be continued after 1945. Nevertheless, after World War II, ceramics began to slowly but surely find its place at the university. The crucial moment in this respect was when the renewed University of Olomouc acquired the personality of Josef Vydra (1884-1959), an art historian, academic painter, ethnographer and critic, and a supporter of modern Czech ceramics. His professional attitudes, pedagogical views and ambitions played a major role in the decision to include ceramics in the education of future teachers.

Vydra was interested in ceramics all his life. He published a number of studies and reports, and reviewed exhibitions in this field (e.g., 1927, 1943, 1948, 1949, 1950, 1957). Completely in accordance with the principles of the muchadmired avant-garde school, Bauhaus, he perceived ceramics as the primary skill and a key prerequisite for students' further creative art activity. In an effort to interconnect the theoretical and practical as well as the artistic, arts and crafts and methodological components of the study as effectively as possible, he established drawing, painting, graphics and modelling in the curriculum as basic studio disciplines and, similarly to Bauhaus, he balanced these subjects with training in workshops focused on mastering craftsmanship and technological aspects of artwork, and on understanding the importance of product design (Kavčáková \& Myslivečková, 2010). Assuming the post of the head of the Institute of Art in Olomouc, he included in the first year of the study programme a theoretical subject designed to introduce students to the technologies and 
history of ceramic production. As the name of the subject - Art Production: Ceramics, Glass Art - suggests, ceramics and glassmaking had to share the allotted time of two hours per week. The lecturer was Vydra himself.

When forming the pedagogical staff, Vydra focused on acquiring personalities who were in accord with the Bauhaus type of school, and who would suit his efforts to build a modern workplace of supranational importance in Olomouc. Vydra offered the position of leading the sculpture and modelling studio, which included a ceramic workshop, to Josef Vinecký (1882-1949), an artist with great international experience (from 1907 he was the head of the workshop of artistic modelling at the Weimar Großherzoglich-Sächsische Kunstgewerbeschule, in 1909 he founded his own ceramic workshop in Sinn, in 1928-1932 he worked in Wroclaw at the Staaliche Akademie für Kunst und Kunstgewerbe, then until 1937 in the Staatliche Kunstschule in Berlin) and extraordinary versatility, which can be perceived in his sculptural expression. Vineckýs work included the field of freestyle and pottery ceramics, which suited Vydra's concept of teaching (recall the Bauhaus principle of the combination of werkmeister - formmeister, which Vinecký adhered to closely). In addition, Vinecký and Vydra held the same views on contemporary Czech ceramic production. They criticised it for being »imprisoned in painted decor « and repeatedly pointed out that it was asking "for a renaissance in the aesthetics of shapes under the influence of purism and constructivist style«. Among Czech artists, they praised the aforementioned Eckert for his »ceramic primitivism in engobes « (Vydra, 1948, pp. 357-384). Vinecký became the first personality among a number of art educators who, with Vydra's theoretical support in the form of lectures, had the professional qualifications to incorporate practical training in ceramics at the University of Olomouc.

However, the entire and most generous project of the first Institute of Art Education in Olomouc began to fail due to politically conditioned school reforms after 1948 and innumerable other obstacles (frequent involuntary relocation of the institute, material difficulties, delays in reconstruction, teaching in temporary premises). In particular, Vydra failed to build a workplace with all of the necessary workshops, including a suitably equipped ceramic workshop. In addition, the ruling party's political screening of employees resulted in Vydra being removed from the post of the head of the institute in 1948 on the grounds of being politically unreliable, and Vinecký was made redundant (due to his long work abroad, his marriage to Le Thorn of German origin, and his artworks leaning towards modernism; for more see Kavčáková, 2009). With the departure of Vinecký, the personality of a teacher who could intensively develop the third-level teaching of ceramics in Olomouc disappeared from the institute.

Despite these changes, ceramics did not disappear from the teacher's art 
field in Olomouc. From the 1948/1949 academic year, the already established lectures of Vydra were supplemented by practical exercises, the content of which was to include ceramic work. It was newly entrusted to sculptor and restorer Karel Lenhart (1904-1978). Although his work also included terracotta, the degree to which he incorporated pure ceramic work in his lessons was reduced to a minimum. Even though there was a pottery wheel at the Olomouc Institute of Art at that time and there was a certain - albeit modest - ceramic workshop, it was used only sporadically during Lenhart's lessons. At this moment, the preferred way of working with students at the then art institute, based on the principle of giving maximum support to the individual interests of students, became crucial for the further development of the history of teaching ceramics in Olomouc. At the Institute of Art Education, another student who was completely taken by ceramics and later became a long-term guarantor of ceramic teaching at Palacký University Olomouc began to develop. His name was Stanislav Vymětal (1929-1992).

Vymětal began studying a double-major in Art Education and English Language at the University of Olomouc at the time when February 1948 gradually ended the discussion on the position of Czech art in socialist culture, when only those who respected official ideological requirements could remain on the official art scene (Petišková, 2005), when the Central Union of Czechoslovak fine artists was established as a state body of control of the art community, and when the new regime did not tolerate even the slightest hint of avant-garde art or thought. The lectures of the ambitious and persistent Vydra on ceramics became so motivating for Vymětal that he began to devote himself intensively to this field. He dusted off the potter's wheel in the student workshop and spent many hours in the routine of mastering his craftsmanship with the aim of conquering shapeless clumps of clay and transferring his creative ideas to them. He consulted with Vydra on the theory of the field and the practice of production, and was interested in contemporary Czech ceramic production. In his master's thesis, entitled Ceramic Ornament - Its Forms and Development (1952), which was also based on lectures by Vydra, he highlighted the aforementioned Otto Eckert, who, according to Vymětal, »understood the requirements of modern artistic ceramics«. For the young Vymětal, Eckert's work was "perfect both in terms of shape and function, as well as in terms of decor and ornamental decoration«. He also adored Eckert for his incessant search for creative attitudes. Vymětal saw one of Eckert's greatest advantages in the sobriety and simplicity of his artistic expression, where he "achieved the unique impact of the work by the simplest and plainest means«. In his master's thesis, Vymětal also criticised the contemporary »exuberant naturalism in decor «, which, according to him, corresponded to »the poor taste of capitalist society, and which is not actually a ceramic decor, but a bad painting painted on ceramics « celebrating the 
so-called »functional and natural ornament, whose aesthetic properties result directly from the perfection of shape and material «. Guided by Vydra and acquainted with the views of Itten (Keramische Formgebung: Werk, 1948, no. 2) and the critique of Tilkovský relating to the personality of Eckert, Vymětal formulated his attitude to ceramic work with the following words: „Once all the proportions of a product are in mutual harmony, if the beauty of the shape is in accord with its purpose and perfection of craftsmanship - then such an object can satisfy all the aesthetic requirements one can ask of it." Without realising it at the time, in his master's thesis, the young student summarised his own lifelong attitude to ceramic work, as well as his respect and admiration for the work of Eckert.

\section{Figure 3}

Stanislav Vymětal, Bottle, 1970s, Regional Museum in Olomouc, photo by P. Rozsíval

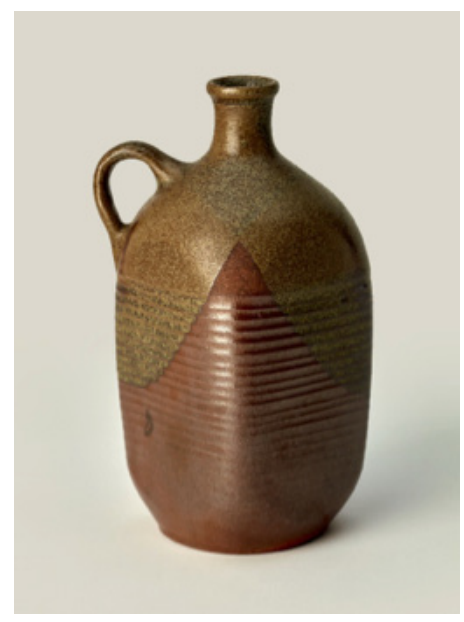

\section{Figure 4}

Stanislav Vymětal, Jug, 1970s, Regional Museum in Olomouc, photo by P. Rozsíval

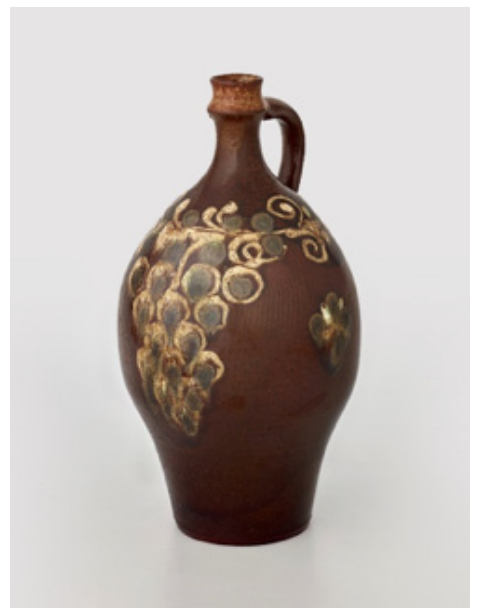

\section{Stanislav Vymětal teaches}

Stanislav Vymětal began working at the University of Olomouc in 1954, a time marked by modernist tendencies in Czech ceramics (despite the entrenched socialist realism as official doctrine) (see more in Petrová, 2005b). Ceramics was given state support in two directions. First of all, it was an artist's experiment, especially in the field of monumental tasks for architecture and garden sculpture; secondly, it was a branch of industrial design. Thanks to his monumental realisations in architecture, which could be found not only 
in Olomouc but also elsewhere in Moravia (e.g., Šternberk, Přerov, Nový Jičín, Hranice na Moravě), as well as his small-scale studio production, Vymětal was part of a group of important Czech artists/ceramists that included Julie Kováčiková-Horová, Pravoslav Rada and Alena Kroupová. He could relate to the accent of the time, especially the demand of the late 1950 s for a hollow shape turned on a potter's wheel combined with handicrafts. His work also reflected the trend of pastel colours and the "dictate « of respect for the function of the object, in which Petrová (2005b, p. 459) rightly sees variants of the Bauhaus principles. Vymětal's earthenware vases, cups, bowls and mugs made on a potter's wheel, as well as his decorative works, are characterised by extraordinary richness in the variety of shapes, the solidity of design, the sober décor, and the earthy colours with many shades of ochre, grey and brown. He respected contemporary society's tendency towards purposeful and harmonious simplicity.

Like his teacher Vydra, Vymětal understood the need for perfect mastery of the craft as a key requirement for high-quality ceramic work. Only on this basis could artistic invention be realised. As Vymětal explains in one of his lectures (1970s): „Creative invention is associated with perfect mastery of production processes and techniques. Knowledge and practical experience in the field of production technology and mastery of craft technical procedures are an important precondition for achieving the set goal. Ceramic work becomes art when a harmonious balance is achieved between mastering the craft and the ability to realise an artistic intention in a given material in a perfect artistic form $«($ pp. 3-4).

Even in teaching, Vymětal's goal was for his students to gain knowledge of the basics of the craftsmanship and technical principles of ceramic work, while obtaining an understanding of the properties and possibilities of ceramic material. He trained his students mainly in a craft routine, contributing to the development of the skill and mastery of working on a potter's wheel. To this he added an emphasis on a narrower understanding of ceramic sculpture as a genre of fine art, which gives us the possibility for the expression of intimate scale and poetic imagery. This was also part of the period goals of Czech freestyle ceramic work, as evidenced by the work of Bohumil Dobiáš Jr., Marie Rychlíková, Lydie Hladíková, Lubor Tehlík, Dagmar Handrychová, Václav Dolejš, and others. The creative passion that Vymětal transferred to teaching was also supported by the atmosphere of the approaching 196os. These were the years of fading enthusiasm from the success of Czechoslovakia at the World Exhibition EXPO 58 in Brussels and the intoxication from other competitions and exhibitions of ceramics at home and abroad, especially at the International Exhibition of Ceramics, which took place in 1962 in Prague under the auspices of 
International Academy of Ceramics. Furthermore, the study programme for teacher training was extended from four to five years in Czechoslovakia in the early 1960 s. The number of hours was increased for the subject of Art Production and Architecture, within which ceramics was taught, and by implication the share of Vymětal's teaching also increased.

\section{Figure 5}

Stanislav Vymětal at work, around 1980, photo private archive

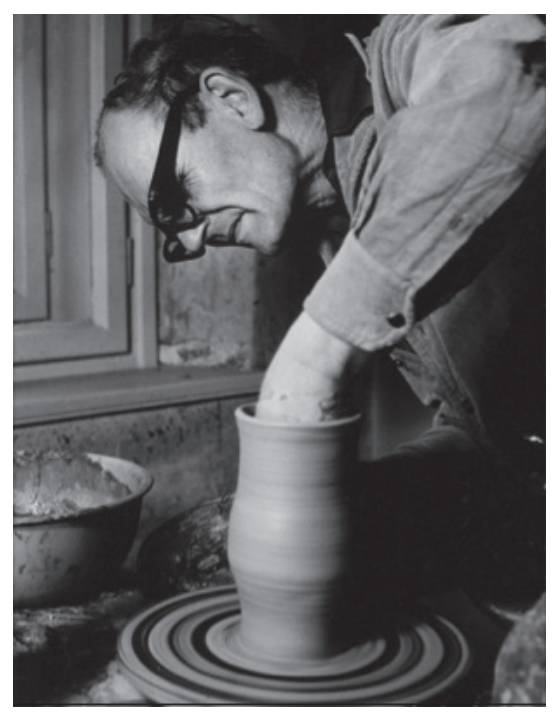

The invasion of the Warsaw Pact troops had an unfortunate impact on the Czech-nation in many ways, but the normalisation of cultural policy did not intervene too destructively in Czech ceramics (Petrová, 2005c), and it essentially continued to find a great deal of support in society. A period text by authors Růžička and Vlček (1979) comments on the position of ceramics in the 1970s. According to them, in the 1970s, ceramics was rediscovered as a means of artistic expression of contemporary sculpture. For its sudden development in recent decades, wider changes in the development of art and in people's lives had become essential. They recognised the urgent need for art to act as a unifying link between nature and civilisation. Ceramics thus became interesting as an area of activity involving both natural and cultural principles of creation. In addition, according to them, the whole process of forming a ceramic object was gaining in importance in an environment determined by modern technology. The University of Olomouc responded to this by introducing a new 
subject called Ceramic Practice. Led exclusively by Vymětal, it was a so-called »recommended lecture «. The position of teaching ceramics in Olomouc in the 1970 is specified in the catalogue of the exhibition of artworks by students of the department held during the celebrations of the $400^{\text {th }}$ anniversary of the University of Olomouc: »The place of ceramics in the overall content of the art education study programme is proportional to the importance of this discipline in the context of industrial art and architecture (...) We strive to ensure that the ceramic products of our students are not self-serving, that they are intended for the fulfilment of certain functions, that they have a social purpose« (1973, without page no.).

When, in 1980, two Olomouc art departments operating in parallel were merged and all of the teacher training art disciplines were integrated into a single Department of Art Theory and Art Education, Vymětal moved from the Faculty of Arts to the Faculty of Education, where he continued to inspire future teachers and awaken their feeling and passion for ceramic work until 1992.

\section{Changes in the 199os and the personality of Jana Bébarová}

In 1989, a revolution broke out in Czechoslovakia. It brought about the fall of the communist regime and opened the way to democracy. Subsequent changes also affected the Department of Art Education in Olomouc. The development of ceramics lessons was mainly influenced by the then head of the art department of the Faculty of Education, Hana Myslivečková, when in 1990 she submitted a proposal for the establishment of a new field of study entitled Art Education for Specialised Schools and Folk Art Schools. In the proposal, ceramics was newly included in the study programme as a separate subject. The approval of the submitted proposal meant a major breakthrough for the position of ceramics within teacher training studies in Olomouc. For the first time since 1946, it began to be taught as a separate compulsory subject! Ceramics no longer had to share the hourly allowance with other arts, as it had before. For all of the students of the newly established single-major five-year study programme, as well as for those who chose a double-major combination with art education for their professional focus, ceramics became a binding experience immediately in the first years of study. Gradually, the established subject Ceramic Work and Methodology transformed into a subject stretching over two semesters and more, and in addition to compulsory status, it acquired an optional subject status intended for those with increased interest in the field as well as for those who chose ceramics as the topic of their thesis. The teaching management was newly entrusted to artist Jana Bébarová, also a graduate of Palacký University. 
Just like Vydra many decades earlier and Vymětal in the period immediately prior, Bébarová considered the craft and its mastery as a key requirement not only for the success of her students' artistic realisations, but also for strengthening their self-confidence, without which they would not be able to implement ceramics in their future pedagogical practice. In accordance with her motto, which says "If teachers do not know how to make ceramics, they will not make it«, she demanded that students master the basic procedures and techniques, as well as learning all of the possible pitfalls that can be encountered in ceramic materials. In addition, in her classes, Bébarová applied not only traditional methods, but also new technologies, which made the whole subject more attractive. Motivated by lectures on the aesthetics, theory and history of art by art critic and theorist Václav Zykmund, which she had attended with enthusiasm during her studies at Palacký University, Bébarová also set education through art as her main goal. This led students to a discussion about fine arts in the broadest sense of the word, and specifically with regard to arts and crafts, the present and the past, and domestic and foreign ceramic work. She also considered it essential to give her students the opportunity to create large-scale sculptures. She rightly perceived the experience with a large format as an essential moment for the personal development of students, conveying to them the feeling of a person dedicated to "great art «, and with this a stunning impression of generosity as well as the necessary tolerance and respect for the work of others. Bébarová also aimed to ensure that future teachers were fully acquainted with the important role of spatial - especially ceramic - work in the educational process. She wanted her students, who were aware of the merits they had achieved in their own work in the field, to have the ability and desire to pass on their experience as well as their theoretical and practical knowledge, and to apply them broadly in their future pedagogical practice.

At a number of solo and group exhibitions by Bébarová, students had the opportunity to confront the value passed on with her own work, in which she always defended her attitudes towards modern ceramic work. Inspired mainly by nature and music, to this day she transforms shapeless lumps of clay into abstract units, thus recording her »feelings from the landscape«. Her objects, reliefs and spatial realisations are in direct harmony with nature; they are a manifestation of respect and reverence for the landscape, its power and the unceasing cycle. » They are the breath of a human being walking through the landscape« (Koval, 2010) and they are a symbol. Bébarová models, imprints into clay, impresses. Although pure craftsmanship is present in everything, her work transcends the boundaries of craftsmanship and turns into freestyle art. In her work, the definition specifying applied and freestyle ceramics thus completely loses its significance. 
On many occasions, Bébarová had to fight to preserve the teaching of ceramics at the university and to defend this field. Moreover, when she first came to the art department, the pottery workshop was in poor condition, with the minimum necessary technical equipment. As she herself states, it was »essentially non-functional, with two obsolete potter's wheels and a burnt-out kiln« (Open Letter to the Dean, 2008, private archive). She had to devote a great deal of time and energy to the difficult task of modernising the workshop. This was made even more difficult by the fact that the art department had to relocate several times. Thanks to her diligence and her belief in the importance of ceramic work for the development of the individual, she was able not only to keep ceramics as a main subject in teaching at the Department of Art Education in Olomouc, but above all to inspire many students, many future teachers. Bébarová was succeeded by one of her graduates, Veronika Selingerová. During her work at the department in the years 2008-2015, she also strove to ensure that students mastered the technological processes of ceramic work, but her primary objective was to stimulate their interest in the field. She consciously motivated students mainly through passionate discussions, revealing her own principle of thinking about the creative process and repeatedly encouraging them to work intensively on their own creative ideas.

\section{Figure 6}

Jana Bébarová, Jana Bébarová, Relief of Rustle, 1980s, Regional Museum in Olomouc, photo by P. Rozsíval

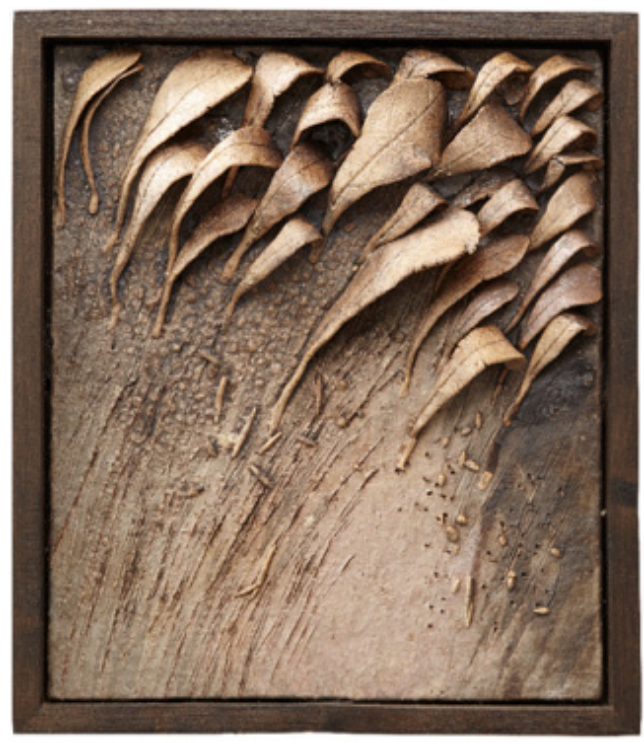




\section{Figure 7}

Jana Bébarová, Bed for Princess, 2008, photo private archive

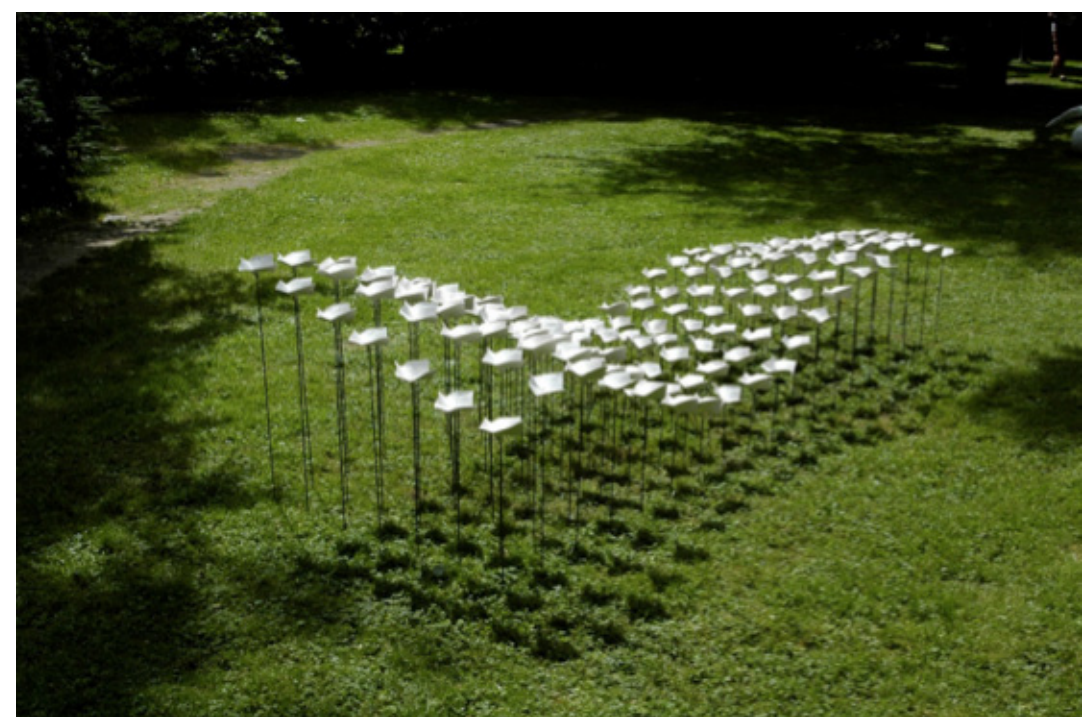

\section{Personalities of contemporary teaching of ceramics}

At present, the guarantor of ceramics at the Department of Art Education in Olomouc is sculptor Robert Buček. Aware of the fact that working with clay is not a matter of course in art lessons at primary or secondary schools, he reconceptualises his approach to teaching ceramics around the requirement that the acquired theoretical and practical knowledge be of the utmost use to students in their future pedagogical activities. During his lessons, he continuously points to the knowledge from psychology, and specifically from the ontogenesis of children's artistic expression, and purposefully leads students to understanding the importance of incorporating work with clay into teaching. Buček aims to break down the prejudice that working with clay is by necessity a complex and technically demanding task, and motivates students to master an expanding range of techniques applicable in art lessons, as well as to pursue their own freestyle expression. His aim is for students to thoughtfully complete their intentions and increase them with the element of self-knowledge in their artistic reactions to the assigned topics. At the same time, he attaches paramount importance to the experience of own creative activity, thanks to which students are able to promote and implement ceramics later in their art education classes. 
Buček has been working at the Department of Art Education in Olomouc since 2014. He shares the teaching of ceramics in the first year of the study programme with Monika Dokoupilová. With the cooperation of these two personalities, the Olomouc Department of Art Education has achieved perfect functionality and above-standard quality teaching of ceramics. In her classes, Dokoupilová mediates the basic techniques of ceramic work to students in the form of practical tasks, acquainting them with production processes from the processing and preparation of clay, through the creation process itself, to firing and glazing. This practical part is complemented by lectures by Buček. From the second year of the study programme, Buček takes over all of the workshops. Since he is not an artist who focuses only on ceramics, but on the contrary, uses a wide range of materials (wood, glass, stone, clay), often combining them, he also naturally offers his students the possibility of this direction. This completely - but not necessarily - eliminates the clear definition of ceramics with regard to other materials. At the same time, the boundary between low and high art, between craft and freestyle creative work, is dismantled. A conservative approach turns into a completely free and stimulating one, providing unlimited creative possibilities. In this concept, both teachers aim not only at the primary goal of leading students to acquiring or consolidating basic knowledge about ceramics, but especially to breaking down the fear of artmaking and to applying their own creativity to their artistic realisations.

\section{Figure 8}

Robert Buček, Well. Being, detail, 2020, photo private archive

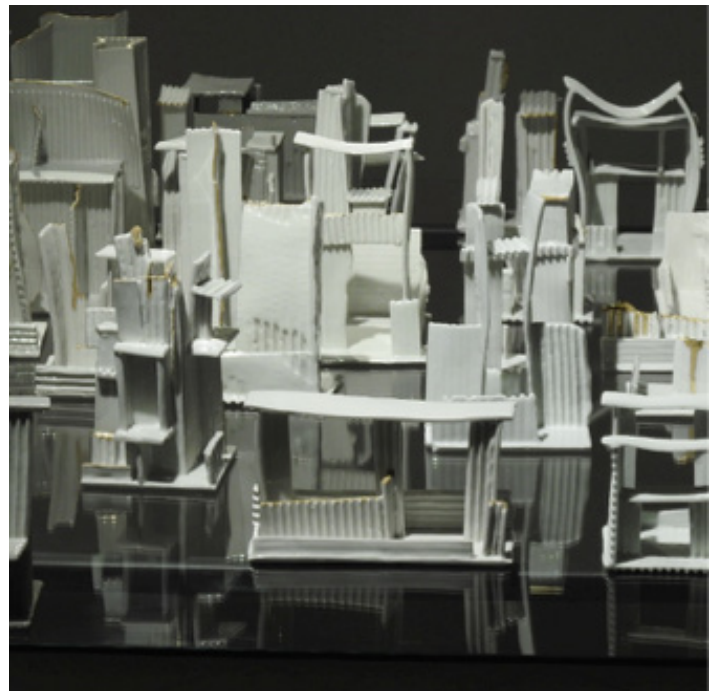




\section{Figure 9}

Robert Buček, Lent Intervention in the Church of Our Lady of the Snows, 2020, Installation in the Church of Our Lady of the Snows in Olomouc, photo private archive

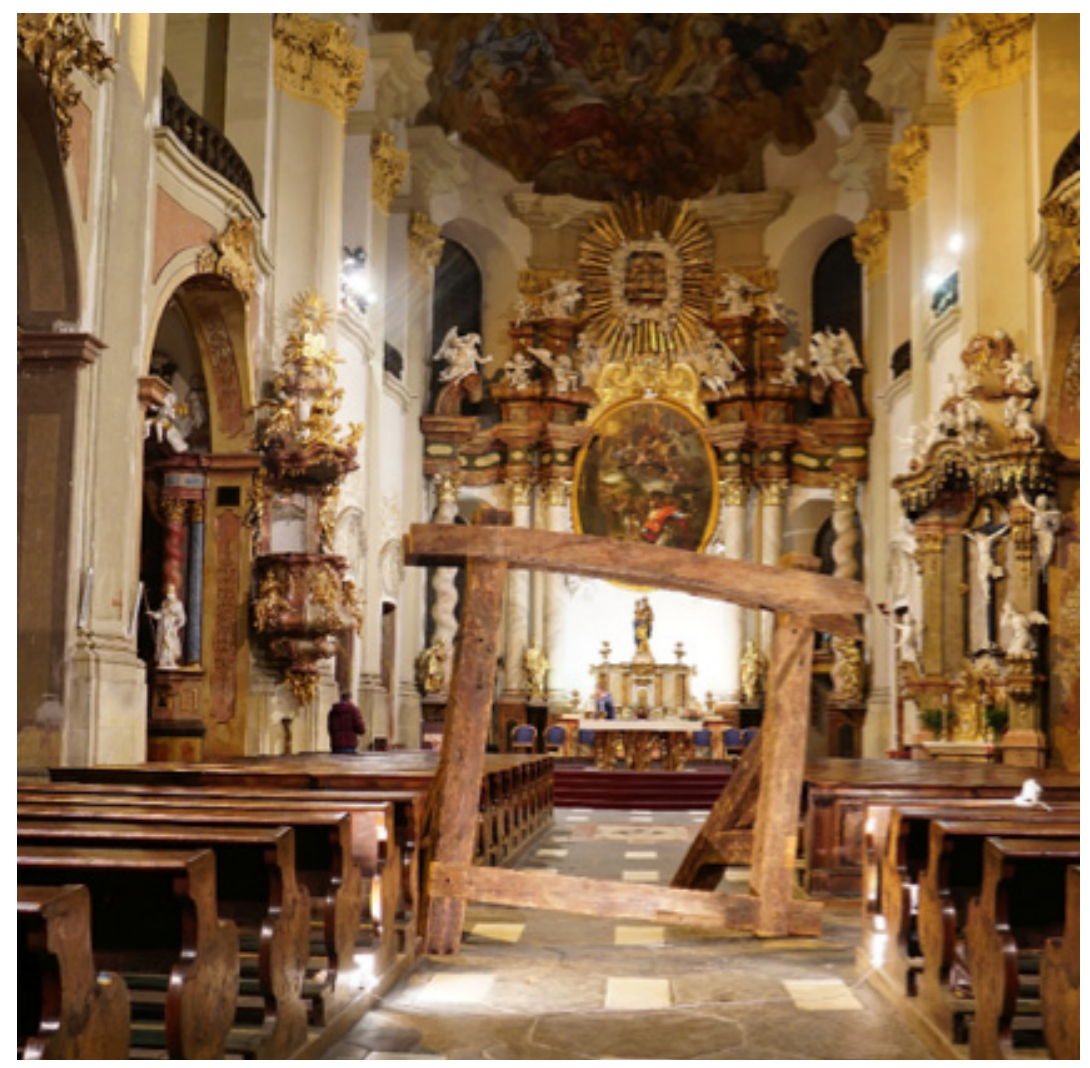

\section{Conclusion}

From the very beginning, third-level teaching of ceramics in Olomouc has taken place against the backdrop of frequent changes in the system of the education of future teachers. In the first post-war years, the professional training of all categories of future teachers in the Czech Republic first belonged to the faculties of art and the newly established pedagogical faculties of universities. From the 1950/1951 academic year, the education of kindergarten and national schoolteachers was excluded from the university setting and entrusted to pedagogical grammar schools. Only a few years later, in 1953, the faculties of education were abolished. Their role was taken over by higher pedagogical schools (for teachers 
of grades 6 to 9) and pedagogical universities in Prague and Olomouc (for teachers of grades 9 to 11 of eleven-grade schools, pedagogical and vocational schools). Five years later, new pedagogical institutes were established by government decree for teacher erudition. However, in 1962, the government of the Czechoslovak Socialist Republic declared that pedagogical institutes were universities, and two years later pedagogical faculties were again established from pedagogical institutes. From the 1964/1965 academic year, the third-level education of art teachers in Olomouc took place in parallel at two art departments: the Faculty of Education and the Faculty of Arts. It was not until 1980 that all teaching disciplines were integrated exclusively under the Faculty of Education. Alternation in the structure of pedagogical education intertwined and clashed with the work of the individual personalities who were selected as essential for the history of university teaching of ceramics in Olomouc by the present research.

Vydra’s initiative personality stood at the beginning, and Myslivečková advocated a post-revolutionary turning point. The practice was, however, determined - with marginal exceptions - by the teachers themselves, who, in addition to their artistic careers, engaged in pedagogical professions. The quality of their teaching always depended on their artistic and pedagogical attitudes, personal interests and artistic ambitions. However, the political circumstances and time itself did not allow Vinecký to develop his full potential. Vymětal's lessons reflected the diligence, kindness and prudence of the teacher, as well as the modesty and disciplined fantasy of the artist/ceramist. Bébarová sacrificed her artistic career to build and actively lead a ceramics studio. Selingerová worked as a teacher for too short a time for the manuscript of her pedagogical work to be inscribed in the direction of the studio. This does not, however, apply to the activities of Buček, whose creative ambitions and pedagogical attitudes are significantly reflected in the direction of teaching ceramics at the University of Olomouc at present. It is thanks to all of these personalities that the Department of Art Education at Palacký University Olomouc can be rightly proud of the long tradition of its teaching of ceramics.

\section{Acknowledgement}

The paper is one of the outcomes of the specific research project, ref. no. IGA_PdF_2020_031 titled Global Narratives in Art Education and Museum and Gallery Education, funded by the Faculty of Education, Palacký University Olomouc, the Czech Republic.

My thanks go to my supervisor Assist. Prof. Dr Hana Myslivečková, CSc, for her inspiring advice and comments. 


\section{References}

Bender, L. (1952). Child psychiatric techniques. Charles Thomas.

Bieberle, J. (1996). Palackého univerzita po normalizačních čistkách [Palacký University after normalisation purges]. Střední Morava, kulturně historická revue, 2(2), 110-113.

Bieberle, J. (2003). Kapitoly z dějin univerzitního školství na Moravě v letech 1945-1990 [Chapters from the history of the university education system in Moravia in 1945-1990]. Střední Morava, 9(17), 139-140.

Bieberle, J. (2011). Univerzita Palackého vážně i s úsměvem: univerzitní léta 1945-199o pohledem historika a bývalého dëkana Filosofické fakulty [Palacký University seriously and with a smile: The university years 1945-1990 from the point of view of a historian and former dean of the Faculty of Arts]. Olomoucké vzdělávací sdružení.

Bieberle, J. (2016). Univerzita Palackého v Olomouci: z historie a každodennosti akademické obce 19451990 [Palacký University Olomouc: From the history and everyday life of the academic community 1945-1990]. Olomoucké vzdělávací sdružení.

Budak, A., Fajt, J., \& Pakesch, P. (Eds.). (2017). Otisky vědění: řeč keramiky [Kneaded knowledge: The language of ceramics]: Edmud de Waal, Ai Weiwei, Lynda Benglis, Alison Britton, Hans Coper, Lucio Fontana, Vlastislav Hofman, Pavel Janák, Asger Jorn, Kazimir Malevich, Fausto Melotti, Joan Miró, Isamu Noguchi, Pablo Picasso, Lucie Rie, Marit Tingleff, Peter Voulkos: Míšeň: raná asijská keramika [Meissen: Early Asian ceramics]. Národní galerie v Praze.

Cikánová, K. (1995). Objevujte s námi tvar [Discover the shape with us]. Aventinum.

Dvořák, J., (Ed.). (1976). Univerzita Palackého: 1946-1976 [Palacký University: 1946-1976]. Univerzita Palackého.

Fiala, J., Kašpar, Z., Mlčák, L., Pojsl, M., Urbášek, P. (2009). Univerzita v Olomouci (1573-2009).

[University in Olomouc (1573-2009)]. Univerzita Palackého v Olomouci.

Horejsek, J. (1996). Padesát let Univerzity Palackého v Olomouce [Fifty years of Palacký University

Olomouc]. Střední Morava, kulturně historická revue, 2(2), 13-17.

Kavčáková, A. (2009). Josef Vinecký (1882-1949): osobnost sochaře v kontextu evropské avantgardy 20. století [Josef Vinecký (1882-1949): The personality of a sculptor in the context of the European avantgarde of the twentieth century]. Univerzita Palackého v Olomouci.

Kavč́ková, A., \& Myslivečková, H. (2010) Josef Vydra (1884 - 1959) v kontextu umělecké a výtvarně pedagogické avantgardy 20. století. Historie a současnost univerzitního výtvarného vzdělávání $v$ Olomouci [Josef Vydra (1884-1959) in the context of the art and art pedagogical avant-garde of the twentieth century. The history and present of university art education in Olomouc]. Univerzita Palackého v Olomouci.

Kouřil, M. (Ed.). (1948). Sjezd národní kultury 1948: Sbírka dokumentů [Congress of National Culture 1948: Collection of documents]. Orbis.

Kováríček, V., et al. (1996). Pedagogická fakulta Univerzity Palackého 1946 - 1996, Padesát let vysokoškolského vzdělávání učitelů [Faculty of Education, Palacký University, 1946-1996, fifty years of 
third-level education for teachers]. TiReSa.

Kováříček, V. (2005). Regionální školství. Řada A, Kraj Olomouc. Školství v Olomouckém kraji v roce 1995 [The regional school system. Series A, Olomouc Region. Education in the Olomouc region in 1995]. Votobia.

Krautter, O. (1930). Die Entwicklung des plastischen Gestaltens beim Vorschulpflichtigen Kinde; ein Beitrag zur Psychogenese der Gestaltung. Beihefte ... zur Zeitschrift f. Psychologie, sv. 50. J. A. Barth. Lowenfeld, V. (1947). Creative and mental growth. A textbook on art education. Macmillan. Myslivečková, H. (2002). Katedra výtvarné výchovy pedagogické fakulty Univerzity Palackého v Olomouci [Department of Art Education, Faculty of Education, Palacký University Olomouc]. In J. Mačáková et al. (Eds.), Jezuitský konvikt: sídlo uměleckého centra Univerzity Palackého v Olomouci: dějiny, stavební a umělecké dějiny, obnova a využití (pp. 319-323). Univerzita Palackého.

Myslivečková, H. (2018). Katedra výtvarné výchovy Univerzity Palackého v Olomouci: tradice a současnost [Department of Art Education, Palacký University Olomouc: Tradition and the present]. In M. Makovský (Ed.), Vybrané vidění. Pozice a strategie výtvarné tvorby v procesu vzdělávání (pp. 121-135). Univerzita Palackého v Olomouci.

Myslivečková, H., \& Šobáňová, P. (2014). Vnímání, tvorba, komunikace [Perception, creation, communication]. Univerzita Palackého v Olomouci.

Navrátil, J. et al. (1973). Kapitoly z dějin olomoucké university 1573-1973. [Selected chapters from the history of the University of Olomouc, 1573-1973]. Profil.

Novák, F. (1976). Třicet let výtvarné teorie a výchovy na Univerzitě Palackého: Zprávy vlastivědného ústavu $v$ Olomouci [Thirty years of art theory and art education at Palacký University: Reports of the Institute of Regional Studies in Olomouc]. Vlastivědný ústav v Olomouci.

Novotná, S. (2019). Výuka keramiky na Univerzitě Palackého v Olomouci v minulosti a dnes (přehledová studie) [Teaching ceramics at Palacký University Olomouc in the past and now]. Kultura, umění a výchova, 7(1).

http://www.kuv.upol.cz/index.php?seo_url=aktualni-cislo\&casopis=17\&clanek=198 Novotná, S. (2019). Vývoj a kvalita výuky keramiky v rámci vysokoškolského vzdělávání [The development and quality of teaching ceramics in university education]. In A. Pospíšil, K. Řepa, \& P. Šobáňová (Eds.), Kvalita ve výtvarné výchově (pp. 215-225). Česká sekce INSEA.

Osten, J. (1965). Vývoj plastického projevu dětí a mladistvých [Development of three-dimensional expression of children and adolescents]. In I. Zhoř \& V. Píša (Eds.), Výtvarná výchova a tvořivost: [Sborník z] 2. celost. konference učitelů výtvarné výchovy (pp. 87-92). Státní pedagogické nakladatelství.

Petišková, T. (2005). Oficiální umění padesátých let [The official art of the 1950s]. In R. Švácha \& M. Platovská (Eds.), Dějiny českého výtvarného umění. Díl V. 1939/1958 (pp. 341-369). Academia. Petrová, S. (2005a). Sklo a keramika 1939-1948 [Glass art and ceramics 1939-1948]. In R. Švácha \& M. Platovská (Eds.), Dějiny českého výtvarného umění. Díl V. 1939/1958 (pp. 267-269). Academia. Petrová, S. (2005b). Sklo a keramika 1948-1958 [Glass art and ceramics 1948-1958]. In R. Švácha \& M. Platovská (Eds.), Dějiny českého výtvarného umění. Díl V. 1939/1958 (pp. 459-463). Academia. 
Petrová, S. (2005C). Sklo a keramika 1970-1989 [Glass art and ceramics 1970-1989]. In R. Švácha \& M. Platovská (Eds.), Dějiny českého výtvarného umění. Díl VI/2. 1958/200o (pp. 840-851). Academia. Přikryl, Z. (Ed.). (1976). Katedra výtvarné výchovy pedagogické fakulty UP k 3o. výročí obnovení vysokého školství v Olomouci [Department of Art Education, Faculty of Education, Palacký University on the $30^{\text {th }}$ anniversary of the renewal of third-level education in Olomouc]. Pedagogická fakulta Univerzity Palackého.

Roeselová, V. (1996). Techniky ve výtvarné výchově [Techniques in art education]. Sarah. Roeselová, V. (1997). Řady a projekty ve výtvarné výchově [Series and projects in art education]. Sarah.

Roeselová, V., et al. (1999). Proudy ve výtvarné výchově [Movements in art education]. Sarah. Růžička, M., \& Vlček, T. (1979). Současná keramika [Contemporary ceramics]. Odeon. Soudobé české umění.

Šicková-Fabrici, J. (2008). Základy arteterapie [Basics of art therapy]. Portál.

Skřivánková, L. (2016). Pod tlakem ideologií: Design a politika 1939-1953 [Under the pressure of ideologies: Design and politics 1939-1953]. In I. Knobloch \& R. Vondráček (Eds.), Design v českých zemích 1900-20oo: instituce moderního designu (pp. 267-269). Academia.

Univerzita Palackého. Pedagogická fakulta. (1984). Pedagogická fakulta Univerzity Palackéhov Olomouci 1964-1984 [Faculty of Education, Palacký University Olomouc, 1964-1984]. Univerzita Palackého.

Univerzita Palackého. Pedagogická fakulta. (2007). Katedra výtvarné výchovy Pedagogické fakulty Univerzity Palackého v Olomouci [Department of Art Education, Faculty of Education, Palacký University Olomouc]. Univerzita Palackého v Olomouci.

Univerzita Palackého. Pedagogická fakulta. (2016). 7o let Pedagogické fakulty Univerzity Palackého v Olomouci 1946-2016 [Seventy years of the Faculty of Education, Palacký University Olomouc, 19462016]. Univerzita Palackého v Olomouci.

Univerzita Palackého. Pedagogická fakulta \& Kováříček, V. (2006a). Kronika za léta 1990-2005: Pedagogická fakulta Univerzity Palackého v Olomouci [Chronicle for the years 1990-2005: Faculty of Education, Palacký University Olomouc]. Pedagogická fakulta Univerzity Palackého v Nakladatelství Olomouc.

Univerzita Palackého. Pedagogická fakulta \& Kováŕíček, V. (2006b). Pocta pracovníkům (1964-2006): Pedagogická fakulta Univerzity Palackého v Olomouci [Tribute to employees (1964-2006): Faculty of Education, Palacký University Olomouc]. Pedagogická fakulta Univerzity Palackého v Nakladatelství Olomouc.

Univerzita Palackého Pedagogická fakulta \& Serafín, Č. (2005). Ohlédnutí: jubilejní kaleidoskop: Pedagogická fakulta Univerzity Palackého 1946-2005 [Looking back: Jubilee kaleidoscope: Faculty of Education, Palacký University, 1946-2005]. Pedagogická fakulta.

Univerzita Palackého v Olomouci 1981: sborník k 35. výročí Univerzity Palackého Olomouci (19461981) [Palacký University Olomouc, 1981: Anthology for the $35^{\text {th }}$ anniversary of Palacký University Olomouc (1946-1981)]. (1983). Univerzita Palackého. 
Univerzita J. E. Purkyně. Myslivečková, H., \& Šobáňová, P. (2007). Vysokoškolská př́prava výtvarných pedagogů - současný stav a perspektivy: sborník př́íspěvků [University-level training of art teachers Current state and perspectives: A collection of papers]. Univerzita Palackého v Olomouci.

Urbášek, P., Pulec, J., Konečný, K., \& Kalendovská, J. (2003). Kapitoly z dějin univerzitního školství na Moravě v letech 1945-199o [Chapters from the history of third-level education in Moravia in the years 1945-1990]. Univerzita Palackého.

Uždil, J. (1970). Vnímání a výtvarný projev. Výtvarný projev dospívající mládeže [Perception and artistic expression. Artistic expression of adolescents]. Ústřední dům lidové umělecké tvořivosti. Uždil, J. (1974). Čáry, klikyháky, paňáci a auta [Lines, scribbles, panners and cars]. SPN.

Uždil, J. (1974). Výtvarný projev a výchova [Artistic expression and education]. Státní pedagogické nakladatelství.

Vydra, J. (1927). Dějiny lidové keramiky ve Stupavě [The history of folk ceramics in Stupava]. J. Štenc. Vydra, J. (1943). Dílna dobré keramiky [A workshop of good ceramics]. Výtvarná výchova, 10(2), 1-4. Vydra, J. (1948). Cesta československé keramiky k umění [The path of Czechoslovak ceramics to art]. Československo, 3(6), 357-384.

Vydra, J. (1949). Keramika Dagmar Rosůlkové-Kubíkové [The ceramics of Dagmar RosůlkováKubíková]. Tvar, 2(1), 31-32.

Vydra, J. (1950). Keramik a sochař Jan Znoj [Ceramist and sculptor Jan Znoj]. Tvar, 3(4),126-127. Vydra, J. (1957). Výstava habánské keramiky [The exhibition of Habani Ceramics]. Umění a řemesla, $1(4), 182-185$.

Vymětal, S. (1952). Keramický ornament - jeho formy a vývoj. diplomová práce [Ceramic ornament Its forms and development] (Master's thesis). Univerzita Palackého v Olomouci.

Vymětal, S. (1970s). Základní rysy a tvưrčí principy keramické tvorby. Keramické techniky ve výuce výtvarné výchovy [Basic features and creative principles of ceramic work. Ceramic techniques in teaching art education]. Private archive.

Výstava výtvarných prací členů katedry výtvarné výchovy na pedagogické fakultě University Palackého v Olomouci: K 25. výr. osvobození [Exhibition of artworks of members of the Department of Art Education at the Faculty of Education, Palacký University Olomouc: On the $25^{\text {th }}$ anniversary of the liberation]. (1970). Univerzita Palackého.

Výstava uměleckých prací pedagogů z kateder výtvarné výchovy filosofické a pedagogické fakulty University Palackého v Olomouci: K 40o. výročí založení Univ. v Olomouci [Exhibition of artworks of teachers from the Departments of Art Education, Faculty of Arts and Faculty of Education, Palacký University Olomouc: On the $400^{\text {th }}$ Anniversary of the founding of the University in Olomouc]. (1973). Univerzita Palackého. Výstava výtvarných realizací členů katedry výtvarné teorie a výchovy v rámci tvưrčí činnosti pro univerzitu palackého v Olomouci [Exhibition of art realisations of members of the Department of Art Theory and Art Education within the creative activity for the Palacký University Olomouc]. (1981). Univerzita Palackého.

Warshawová, J., \& Phethean, R. (1999). Velké kniha keramiky [The big book of ceramics]. Rebo Productions. 
Zeman, M. (Ed.). (2007). Václav Tikal. Vltavín.

Zhoř, I. (1995). Výtvarná výchova v projektech I (pracovní sešit pro 6. a 7. ročník) [Art education in projects I (Workbook for $6^{\text {th }}$ and $7^{\text {th }}$ grades)]. Tobiáš.

Zhoř, I. (1996). Výtvarná výchova v projektech I (pracovní sešit pro 8. a 9. ročník) [Art education in projects I (Workbook for $8^{\text {th }}$ and $9^{\text {th }}$ grades)]. Tobiáš.

Žižková, L. (2008). Slavné počátky a neslavné konce Krásné jizby a Ústředí lidové umělecké

výroby. [The glorious beginnings and infamous ends of Krásná jizba and the Center for Folk Art

Production]. Národopisná revue, 18(3), 127-134.

\section{Biographical note}

Silvie Novotná, Mgr. et Mgr., is an assistant professor in the field of art history at the Department of Art Education, Faculty of Education, Palacky University Olomouc, Czech Republic. She is an art historian and a postgraduate student. She is also employed as a curator in the Regional Museum in Olomouc. Her research interest currently focuses on the history of education in the field of ceramics at Palacky University Olomouc. 